\title{
RELATIONSHIP BETWEEN A HOST PLANT COMPOUND, MYRCENE AND PHEROMONE PRODUCTION IN THE BARK BEETLE, IPS PARACONFUSUS
}

\author{
J. A. Byers, D. L. Wood, L. E. Browne, R. H. Fish*, B. Piatek† and L. B. Hendry \\ Department of Entomological Sciences, University of California, Berkeley, CA 94720, U.S.A.
}

(Received 14 August 1978; revised 22 December 1978)

\begin{abstract}
The pheromonal components, ipsenol and ipsdienol were found in increasing quantities in hindguts of only the male sex of Ips paraconfusus following exposure of both sexes to a series of increasing concentrations of myrcene vapour. Hindguts of female and male beetles contained similar quantities of myrcene and other volatile compounds associated with myrcene exposure. Unexposed beetles of both sexes did not contain detectable amounts of any volatile compound. This indicates that myrcene induces or is a precursor for sex-specific pheromone biosynthesis.

Key Word Index: Ips paraconfusus, Pinus ponderosa, pheromone biosynthesis, bark beetle, myrcene. precursor, ipsdienol, ipsenol, cis-verbenol, attractants.
\end{abstract}

\section{INTRODUCTION}

SEvERAL investigations have indicated that host plant compounds may be converted by insects (EDGAR et al., 1973; HUGHES, 1974; SCHNEIDER et al., 1975; RENWICK et al., 1976a; HugHEs and ReNwick, 1977) or symbiotic microorganisms (BraND et al., 1975) to pheromones that elicit attraction. However, these studies have not quantified the relationship between the precursor exposure dose and subsequent pheromone production. Furthermore, none of these studies utilized a behavioural assay to substantiate the existence of pheromones.

In the bark beetle Ips paraconfusus (Lanier) only the males boring in ponderosa pine have been shown to attract beetles of both sexes in either field (WOOD and VITE, 1961) or laboratory (WoOD, 1962; WoOD and Bushing, 1963) bioassays. The pheromone has been shown to accumulate in the hindgut of males (PITMAN et al., 1965; RENwICK et al., 1966; VITÉ et al., 1972) and was first identified from male frass as a mixture of ipsenol (2-methyl-6-methylene-7-octene-4-ol), cisverbenol (cis-4,6,6-trimethylbicyclo [3.1.1] hept-3-en2-ol), and ipsdienol (2-methyl-6-methylene-2,7octadien-4-ol) (Silverstein et al., 1966a, b).

Several studies have indicated that all three pheromones may be synthesized from host compounds by direct conversion or by induction of synthesis. Brand et al.(1975) showed that a bacterium isolated from the hindgut of $I$. paraconfusus could convert $( \pm) \alpha$-pinene to cis-verbenol and transverbenol in vitro. ReNwick et al. (1976a) reported that both sexes produced cis-verbenol when exposed to vapour of the $(-)$ enantiomer of $\alpha$-pinene. HuGHES

- Pesticide Chemistry and Toxicology Laboratory, Department of Entomological Sciences, University of California, Berkeley, CA 94720 , U.S.A.

†Department of Chemistry, Pennsylvania State University, University Park, PA 16802, U.S.A.

$\ddagger$ Present address: Department of Medicine, Medical College of Georgia, Augusta, GA 30901, U.S.A.
(1974) and HugHES and RENwick (1977) have shown that the host terpene, myrcene, in vapour phase may be a precursor for direct conversion or might induce biosynthesis of ipsdienol, which then may be converted to ipsenol. This latter conversion has been confirmed with deuterium labelled ipsdienol (FISH $e t$ al., in press). The myrcene conversion to ipsdienol remains equivocal, however, since the myrcene used by Hughes (1974) and Hughes and ReNwICK (1977) contained impurities and the suspected pheromone products were identified by GLC retention time (HugHes, 1974) or GCMS (no data given; HUGHES and RENWICK, 1977). Furthermore, females were either not exposed to myrcene (HuGHES, 1974) or exposed to one concentration (not determined; HugHes and RENWICK, 1977) so the possibility of sexual specificity in pheromone biosynthesis from myrcene has not been established.

The objectives of this study were to quantify the relationship between the concentration of the host plant compound in the vapour phase as well as subsequent pheromone production in each sex and to determine the identity of these compounds by several spectroscopic, chemical and behavioural techniques.

\section{MATERIALS AND METHODS}

Ponderosa pine logging debris containing callow adults was collected on 29 March 1976, near the University of California's Blodgett Experimental Forest (El Dorado, county) at an elevation of $1200 \mathrm{~m}$. The beetles were collected (BROWNE, 1972), reared and separated by sex (WoOD, 1961) when they emerged as mature adults.

Myrcene was purified by GLC on a $3 \mathrm{~m} \times 8 \mathrm{~mm}$ i.d. glass column of $3 \%$ A piezon L. on 100/120 Gas Chrom $Q$ at $110^{\circ} \mathrm{C}$ and $\mathrm{N}_{2}$ flow of $300 \mathrm{ml} / \mathrm{min}$ (Varian f.i.d. model 2700). A series of increasing concentrations of myrcene vapour was obtained by placing $0-200 \mu l$ of purified myrcene ( $>99.8 \%$ ) on $1 \times 2 \mathrm{~cm}$ strips of glass fibre paper (GF/A Whatman) inside 0.451 amber- 
coloured glass bottles. Between 20 and 100 beetles of one sex were added to each bottle along with $0.6 \mathrm{~g}$ of silane treated glass wool so that the beetles could disperse and not bite off each other's appendages. Each bottle's aluminium lined cap was drilled and fitted with a GLC rubber septum $(7 \mathrm{~mm})$ to enable the sampling of air with a syringe.

Beetles were exposed to various concentrations of myrcene vapour for $18 \pm 1 \mathrm{hr}$, at $23 \pm 3^{\circ} \mathrm{C}$ under natural light (9 April-5 May 1976). Samples of air were withdrawn from the bottles during the exposure period and the quantity of myrcene per $\mathrm{ml}$ of air was determined by GLC analysis using a $1.8 \mathrm{~m} \times 2 \mathrm{~mm}$ i.d. glass column of $10 \%$ FFAP on $80 / 100$ Gas Chrom $Q$ at $50^{\circ} \mathrm{C}$ and $\mathrm{N}_{2}$ flow of $30 \mathrm{ml} / \mathrm{min}$.

After the exposure period, the posterior portion of the beetles' guts, including the mid- and hindguts, were removed and immediately crushed in $0.4 \mathrm{ml}$ of diethyl ether. The gut extracts were analyzed on two GLC columns, the FFAP column previously described but at $100^{\circ} \mathrm{C}$ and a $1.8 \mathrm{~m} \times 2 \mathrm{~mm}$ i.d. glass column of $3 \%$ Apiezon $\mathrm{L}$ on $100 / 120 \mathrm{Gas}$ Chrom Q at $100^{\circ} \mathrm{C}$ and $\mathrm{N}_{2}$ flow of $12 \mathrm{ml} / \mathrm{min}$. The quantities of ipsenol and ipsdienol per gut were determined by comparison of GLC peak areas with known amounts of these compounds ( $>97 \%$, Chemical Samples Co.) which had been checked for authenticity by GC-CIMS.

GC-CIMS also was used to determine if ipsenol and ipsdienol were present in either unexposed beetles or in beetles exposed to myrcene vapours. Groups of 100 beetles were exposed to the vapours from $30 \mu \mathrm{l}$ of myrcene in the 0.451 bottles. A total of 300 beetles of each sex were exposed and their hindguts extracted with ether. An equal number of unexposed control beetles were treated similarly. These extracts were analyzed for ipsenol, ipsdienol and myrcene on a Finnigan 9500 GLC using several different columns (DEGS, FFAP, OV-1, and Carbowax 20M). A complete separation of all components was obtained on $3 \%$ Carbowax $20 \mathrm{M}$, and this substrate was used in a Finnigan $3200 \mathrm{GC}-$ CIMS with an interactive 6000 digital data system using methane or isobutane as the reagent gas. The male extracts were treated with on- column hydrogenation (Beroza and SARMiENTo, 1966) and analyzed by gcms.

The responses of female beetles in the laboratory assay were used to verify the chemical identifications and to detect low levels of pheromones in exposed and untreated beetles of both sexes. In previous studies two binary mixtures, ipsenol plus ipsdienol and ipsenol plus cis-verbenol attracted walking beetles of both sexes in the laboratory assay (WOOD, 1970). However, since none of these compounds are attractive alone, we assayed for the presence of ipsenol or ipsdienol in females exposed to myrcene vapours by adding either ipsenol or cis-verbenol plus ipsdienol to extracts of female guts. The assay was essentially that developed previously (BROWNE et al., 1974) except that the polyurethane foam was removed from the plexiglass manifold to increase the air flow to $0.9 \mathrm{~m} / \mathrm{sec}$ at the pheromone elution source and $0.6 \mathrm{~m} / \mathrm{sec}$ where the beetles were released $(21 \pm 2 \mathrm{~cm}$ 'downwind'). A positive response was recorded when a female arrived within a $1 \mathrm{~cm}$ radius of the source in the time required for the test sample to elute from a $5 \mu$ l capillary tube $(126 \pm 10 \mathrm{sec})$.

\section{RESULTS}

The theoretical quantity of myrcene necessary to saturate the air in the $0.45 \mathrm{I}$ bottle (about $8.3 \mu \mathrm{l}$ myrcene) can be predicted from the Perfect Gas Law (Williams and Williams, 1967). However, the actual amount required to reach saturation in each bottle (Table 1) was at least 10 times higher than the theoretical amount. GLC analysis of bottles which initially contained myrcene vapour, followed by repeated flushing with $\mathrm{N}_{2}$, indicated that adsorption of myrcene on glass surfaces may account for at least some of this discrepancy.

The percentage of beetles which became comatose increased to near $100 \%$ as the concentration of myrcene vapour was increased to near saturation (Table 1). High concentrations of myrcene and other monoterpenes have been reported to be toxic to other bark beetle species attacking ponderosa pine (SMITH,

Table 1. The relationship between the amount of myrcene added to the bottle and the concentration ${ }^{*}$ of myrcene in the headspace and the subsequent production of ipsenol and ipsdienol in male $I$. paraconfusus

\begin{tabular}{|c|c|c|c|c|c|c|c|c|c|}
\hline & \multicolumn{9}{|c|}{$\mu l$ Myrcene added to aeration chamber } \\
\hline & 0 & 2.1 & 1.6 & $9+$ & 12.7 & 24.1 & 45.8 & 74 & $93 \ddagger$ \\
\hline $\begin{array}{l}\text { Concentration of myrcene in } \\
\text { headspace }\left(10^{-7} \mathrm{~g} / \mathrm{ml}\right)\end{array}$ & - & 3.4 & 6.8 & 10 & 13.5 & 24.5 & 40.3 & 57.5 & 66.1 \\
\hline Per cent comatose & 0 & 0 & $\mathbf{0}$ & 0 & 1 & 3 & 10 & 60 & 95 \\
\hline $\begin{array}{l}\text { Amount of ipsenol produced } \\
\text { per male }\left(10^{-8} \mathrm{~g}\right)\end{array}$ & - & 12.5 & 21.5 & 26.2 & 29.8 & 37.3 & 19.4 & 16.8 & 15.3 \\
\hline $\begin{array}{l}\text { Amount of ipsdienol produced } \\
\text { per male }\left(10^{-8} \mathrm{~g}\right)\end{array}$ & - & 2.2 & 4.2 & 5.3 & 6.1 & 7.7 & 4.4 & 3.7 & 3.1 \\
\hline
\end{tabular}

- The concentrations of myrcene were calculated from a quadratic least squares regression of $\mathbf{5 0}$ data pairs covering the entire range from 0 to $200 \mathrm{mg}$ per chamber $\left(y=-0.00326 x^{2}+1.00069 x+\right.$ 1.31667)

+ Theoretical saturation.

$\ddagger$ Near actual saturation. 


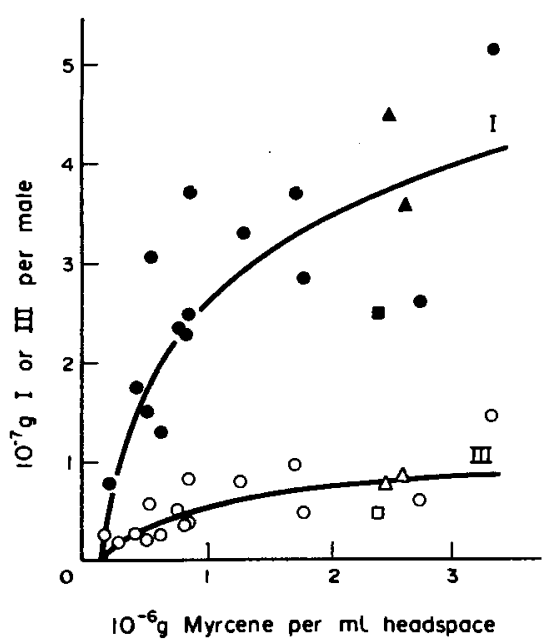

Fig. 1.I (ipsenol) and III (ipsdienol) production in male $I$. paraconfusus after exposure to myrcene vapours. Solid symbols report production of ipsenol while open symbols report production of ipsdienol.

O Represent average of 20 beetles.

$\square$ Represent average of 100 beetles.

$\triangle$ Represent average of 200 beetles.

Equation for logarithmic regression of $\mathrm{I}$ is $y=-2.44+$ $12.45 \ln x$ and correlation coefficient of 0.81 while equation for logarithmic regression of 111 is $y=-1.23^{\circ}+2.84 \ln x$ and correlation coefficient of 0.71 .

1965a, b). Approximately half of the comatose beetles recovered at least partial locomotory capability in 5-15 min. Not unexpectedly, as the per cent of comatose beetles increased ( $>24.1 \mu \mathrm{l}$ of myrcene in the bottle), the amount of ipsenol and ipsdienol production decreased in spite of the exposure to increasing concentrations of myrcene (Table 1).

The curves of ipsenol and ipsdienol production in males exposed to increasing concentrations of myrcene (Fig. 1) have approximately the same $K_{m}$ value (myrcene concentration at half maximal rate of ipsenol or ipsdienol production, $c a .0 .65 \times 10^{-6} \mathrm{~g} / \mathrm{ml}$ ) indicating a common rate limiting step in the biosynthetic pathway (such as the conversion of myrcene to ipsdienol).

GC-CIMS analyses of gut extracts from male beetles exposed to myrcene vapours showed three major components (Fig. 2B) having retention times and mass spectra identical to standard myrcene, ipsenol ([M$\left.17]^{+}, m / e=137\right)$ and ipsdienol $\left([\mathrm{M}-17]^{+}, m / e=135\right)$ (Fig. 2A). Female beetles exposed to myrcene contained only myrcene (Fig. 2C). Volatile compounds were not detected in either male or female control beetles (Fig. 2D and 2E) which were analyzed at 10 times the sensitivity of that in the myrcene treated males. Coinjection of standard ipsenol and ipsdienol with the gut extract of myrcene treated males intensified only the appropriate peaks. On-column hydrogenation of the male gut extract revealed a disappearance of the expected ipsenol and ipsdienol peaks with concomitant formation of a new compound having the retention time and mass spectra of a saturated ten carbon alcohol, 2,6-dimethyl-octan4-ol, $\left([\mathrm{M}-17]^{+}, m / e=141\right)$. Standard ipsenol and
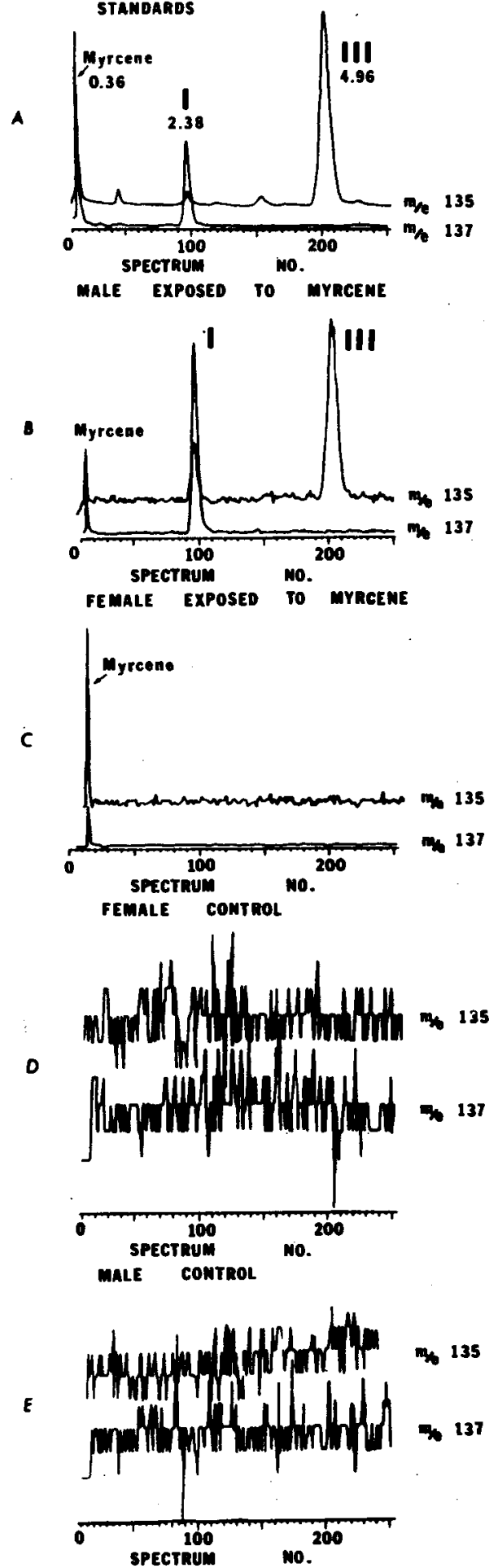

Fig. 2. GC-CIMS analyses of compounds isolated from male and female $I$. paraconfusus exposed and unexposed to myrcene vapours. (A) Reconstructed chromatogram of I (ipsenol) and III (ipsdienol) standards by GC-CIMS Numbers under compound symbols are retention times in min. on Carbowax $20 \mathrm{M}$ at $100^{\circ} \mathrm{C}$. The $m / e 135$ and 137 are the $[\mathrm{M}-17]^{+}$ions used to identify III and I respectively. (B) Males exposed to myrcene. (C) Females exposed to myrcene. (D-E) Ten-fold increase in sensitivity for female (D) and male (E) controls over sensitivity in B-C. 
J. A. BYers et al.

Table 2. Response of female 1 . paraconfusus to pheromonal components ( 1 = ipsenol; 11 = cis-verbenol; $111=$ ipsdienol) and to gut extracts from beetles exposed to various treatments in the bioassay

\begin{tabular}{|c|c|c|c|c|}
\hline Extract & $\begin{array}{c}\text { Rate of delivery } \\
\text { per min } \\
\text { per compound }\end{array}$ & $\begin{array}{l}\text { Per cent } \\
\text { females } \\
\text { responding }\end{array}$ & $(\text { C.I. })^{\star}$ & $\begin{array}{c}\text { Number } \\
\text { of } \\
\text { females }\end{array}$ \\
\hline \multicolumn{5}{|c|}{$\begin{array}{l}\text { Assay for presence of } 1 \text { and Ill together } \\
\text { (20 April 1976) }\end{array}$} \\
\hline $\begin{array}{l}\text { Female guts } \\
\text { (no myrcene) }\end{array}$ & $\begin{array}{l}0.09 \text { gut } \\
\text { equivalents }\end{array}$ & $2^{a}$ & $(0-8)$ & 60 \\
\hline $\begin{array}{l}\text { Male guts } \\
\text { (no myrcene) }\end{array}$ & $\begin{array}{l}0.09 \text { gut } \\
\text { equivalents }\end{array}$ & $3^{a}$ & $(1-12)$ & 60 \\
\hline $\begin{array}{l}\text { Female guts } \\
\text { (myrcene) } \dagger\end{array}$ & $\begin{array}{l}0.09 \text { gut } \\
\text { equivalents } \ddagger\end{array}$ & $2^{a}$ & $(0-8)$ & 90 \\
\hline $\begin{array}{l}\text { Male guts } \\
\text { (myrcene) } \$\end{array}$ & $\begin{array}{l}0.09 \text { gut } \\
\text { equivalents }\end{array}$ & $59^{d}$ & $(48-69)$ & 90 \\
\hline$I+I I I$ & $8.9 \times 10^{-10} \mathrm{~g}$ & $23^{b}$ & $(11-38)$ & 40 \\
\hline$I+I 11$ & $8.9 \times 10^{-0} \mathrm{~g}$ & $33^{b c}$ & $(17-52)$ & 30 \\
\hline$I+I I I$ & $8.9 \times 10^{-8} \mathrm{~g}$ & $57^{\text {rd }}$ & $(38-75)$ & 30 \\
\hline $1+I I I$ & $8.9 \times 10^{-7} \mathrm{~g}$ & $70^{d}$ & $(51-85)$ & 30 \\
\hline
\end{tabular}

\begin{tabular}{|c|c|c|c|c|}
\hline \multicolumn{5}{|c|}{$\begin{array}{l}\text { Assay for presence of III only } \\
\text { (29 July 1976) }\end{array}$} \\
\hline 1 & $8.9 \times 10^{-9} \mathrm{~g}$ & $13^{a}$ & $(4-47)$ & 40 \\
\hline $1+11 I$ & $\begin{array}{l}8.9 \times 10^{-9} \mathrm{~g}+ \\
1.8 \times 10^{-10} \mathrm{~g}\end{array}$ & $50^{b}$ & $(32-69)$ & 30 \\
\hline $\begin{array}{l}\text { I + Female guts } \\
\text { (myrcene) }\end{array}$ & $\begin{array}{l}8.9 \times 10^{-9} \mathrm{~g}+ \\
0.8 \text { gut equiv. } \ddagger\end{array}$ & $7^{a}$ & $(5-19)$ & 30 \\
\hline $\begin{array}{l}\text { I + Female guts } \\
\text { (myrcene) } \dagger\end{array}$ & $\begin{array}{l}8.9 \times 10^{-9} \mathrm{~g}+ \\
0.8 \text { gut equiv } t\end{array}$ & $10^{a}$ & $(2-27)$ & 30 \\
\hline \multicolumn{5}{|c|}{$\begin{array}{l}\text { Assay for presence of I only } \\
\text { (7 November 1977) }\end{array}$} \\
\hline I & $8.9 \times 10^{-10} \mathrm{~g}$ & $10^{\circ}$ & $(2-26)$ & 30 \\
\hline $11+I I I$ & $8.9 \times 10^{-10} \mathrm{~g}$ & $7^{a}$ & $(0-22)$ & 30 \\
\hline$I+I I+I I I$ & $8.9 \times 10^{-10} \mathrm{~g}$ & $43^{b}$ & $(25-62)$ & 40 \\
\hline $\begin{array}{l}\text { II }+ \text { III + Female } \\
\text { guts (myrcene) } \S\end{array}$ & $\begin{array}{l}8.9 \times 10^{-10} \mathrm{~g}+ \\
0.08 \text { gut equiv. }\end{array}$ & $10^{\circ}$ & $(2-24)$ & 40 \\
\hline $\begin{array}{l}\text { II + III + Female } \\
\text { guts (myrcene) } \dagger\end{array}$ & $\begin{array}{l}8.9 \times .10^{-10} \mathrm{~g}+ \\
0.08 \text { gut equiv. } \ddagger\end{array}$ & $0^{\circ}$ & $(0-12)$ & 30 \\
\hline
\end{tabular}

- Confidence intervals were estimated from a chart of binomial confidence limits $(95 \%)$ for proportions.

+ Exposed to $2.4 \times 10^{-6} \mathrm{~g}$ myrcene $/ \mathrm{ml}$ headspace.

‡ No I or III detected in gut extract by GCL.

$\$$ Exposed to $3.1 \times 10^{-6} \mathrm{~g}$ myrcene/ml headspace.

$4.5 \times 10^{-8} \mathrm{~g} \mathrm{I}$ and $1.3 \times 10^{-8} \mathrm{~g}$ III released per min in gut extract (GLC).

II Exposed to $9.1 \times 10^{-7} \mathrm{~g}$ myrcene/ml headspace.

Per cent females responding followed by the same letter are not significantly different at $P=0.05$ using the normal approximation of the binomial distribution for comparing two binomial populations.

ipsdienol under the same hydrogenation conditions gave results identical to the male extract. From the above data, it was concluded that ipsenol and ipsdienol are present in myrcene treated $I$. paraconfusus males and not $\left(<10^{-10} \mathrm{~g} /\right.$ beetle $)$ in females or in unexposed, recently emerged, beetles of either sex.
The response of females in the assay to mixtures of gut extracts from females exposed to myrcene vapours plus ipsenol or the same extract plus cis-verbenol and ipsdienol was not different from the response to ipsenol alone or cis-verbenol and ipsdienol together (Table 2). These assay results confirm the GLC and GC-CIMS data that females do not produce ipsenol 
or ipsdienol at least at the release rates tested in the bioassays. Additionally, they confirm that males produce these pheromones and that the amounts estimated in the male extracts were attractive at levels comparable to synthetic compounds. These results indicate the absence of other compounds in the male extracts that would reduce the female response. However, higher levels of extract than released in this study might reveal the presence of such inhibitory compounds.

Several unidentified compounds were produced by both males and females when exposed to myrcene. These compounds apparently are not attractive to $I$. paraconfusus females, nor could they substitute for ipsenol, cis-verbenol, or ipsdienol since female extracts were not attractive at the levels tested when combined with various pheromone compounds in the bioassay (Table 2).

\section{DISCUSSION}

In previous studies where bark beetles have been exposed to terpene hydrocarbons, the concentration of the compounds in the air was either not determined or reported to be 'saturated', although no analyses were presented (VITÉ et al., 1972; HUGHES, 1973, 1974, 1975; RENWICK et al., 1976a, b; HuGHES and Renwick, 1977). Our results show that the concentration of a volatile compound within a chamber cannot be predicted accurately based on theoretical assumptions; however, the concentration can be determined by GLC.

Hughes (1974) and Hughes and ReNwICK (1977) found that male I. paraconfusus produced ipsenol and ipsdienol when exposed to one concentration of myrcene vapour. We questioned these results because: (1) the suspected precursor was not purified and could have contained the pheromones or compounds that might serve as precursors; (2) the chemical identifications were based only on one GLC column (FFAP) which cannot separate ipsenol from linalool, a compound that has been isolated from headspace volatiles from feeding females (Young et al., 1973). Also FFAP cannot separate ipsdienol from transverbenol, which is known to occur in the beetle (VITÉ $e t$ al., 1972; RENWICK et al., 1976a); and (3) bioassays were not performed to confirm that the isolated compounds were pheromones. In addition to obtaining the data necessary to verify the identity of ipsenol and ipsdienol in hindguts from males exposed to myrcene, we established the quantitative relationship between precursor dosage and subsequent pheromone production.

The relationship between myrcene dosage and ipsenol and ipsdienol production is similar to enzyme reaction rate curves and shows classical saturation effects at the higher concentrations of myrcene (LeHNINGER, 1970). These relationships also could be a result of the saturation of systems for the transport of myrcene across cell membranes. The logarithmic correlation between myrcene exposure and pheromone production provides additional evidence for a direct conversion of myrcene. However, alternative mechanisms such as induction of de novo synthesis or release of sequestered precursors of pheromones are still possibilities.
Females exposed to concentrations of myrcene similar to males did not produce ipsenol and ipsdienol (at least $<10^{-10} \mathrm{~g} /$ female) although comparable quantities of myrcene and other unidentified compounds associated with myrcene exposure were isolated from their hindguts. This indicates that pheromone production resides in male-specific biosynthesis mechanisms and not in the differential penetration of myrcene into the hindgut or other body tissues.

Linalool has been reported to occur in headspace volatiles from only female $I$. paraconfusus feeding in ponderosa pine (Young et al., 1973). However, we did not detect linalool using the Apiezon GLC column in either male or female beetles exposed to myrcene. It is theoretically possible that myrcene could be converted to either ipsdienol or linalool via the monooxygenase present in the beetle; however, myrcene apparently is not converted to linalool in I. paraconfusus.

In earlier studies, suspected pheromones obtained from I. paraconfusus (Hughes, 1974; Hughes and RENWICK, 1977) and from cultures of bacteria isolated from the beetle's hindgut (BRAND et al., 1975) were identified only using GCMS techniques which did not distinguish enantiomers of these pheromones. Therefore, the possibility that these suspected pheromones were biologically inactive enantiomers of the pheromones can not be ruled out (Woon et al., 1976; BORDEN et al., 1976) unless a bioassay is utilized. In the laboratory assay, females responded to gut extracts of males exposed to myrcene indicating that both ipsenol and ipsdienol were produced. None of the three pheromone components, ipsenol, cis-verbenol, or ipsdienol, are active by themselves in the laboratory assay nor is the mixture of $c i s$-verbenol and ipsdienol (WoOd, 1970; Silverstein et al., 1967). These results were verified in field assays (WoOD et al., 1967, 1968). Therefore, any one of these compounds or the one binary mixture could have been produced by females and consequently would not have elicited a behavioural response as shown in earlier studies (WOOD and VITE, 1961; WOOD and BUSHING, 1963; WoOD et al., 1966; WoOD et al., 1968). However, the assay of various mixtures of pheromones show that females exposed to a range of myrcene concentrations did not produce ipsenol or ipsdienol, at least in amounts detectable by bioassay and by GC-CIMS.

BRAND et al. (1975) have shown that Bacillus cereus, cultured from the hindguts of both male and female $I$. paraconfusus, could biosynthesize one of its pheromone components, cis-verbenol, from racemic $\alpha$-pinene, another common monoterpene of host (ponderosa pine) oleoresin. RENwICK et al., (1976a) showed that $c i s$-verbenol could be synthesized by male and female $I$. paraconfusus exposed to vapours of the $(-)$ enantiomer of $\alpha$-pinene. If ipsenol and ipsdienol also are synthesized by a bacterial enzyme system, then these bacteria may be symbionts specific to the male. Recent evidence indicates that synthesis of ipsenol and ipsdienol may be under hormonal control (HuGHES and RENWICK, 1977). Although we have identified and quantified the pheromone components produced in $I$. paraconfusus after exposure to myrcene, elucidation of the biosynthetic processes involved still requires experiments utilizing labelled myrcene (HENDRY et al., submitted, for publication). 
Acknowledgements - These studies were supported in part by the Rockefeller Foundation and U.S. Forest Service and Regional Research project W-110, S.E.A./U.S.D.A.

\section{REFERENCES}

Beroza M. and SARMIENTo R. (1966) Apparatus for reaction gas chromatography. Analyt. Chem. 38, 1042.

Brand J. M., Bracke J. W., Markovetz A. J., Wood D. L. and Browne L. E. (1975) Production of verbenol pheromone by a bacterium isolated from bark beetles. Nature, Lond. 254, 136-137.

Borden J. H., Chong L., Mclean J. A., Slessor K. N. and MORI K. (1976) Gnathotrichus sulcatus: synergistic response to enantiomers of the aggregation pheromone sulcatol. Science 192, 894-896.

Browne L. E. (1972) An emergence cage and refrigerated collector for wood-boring insects and their associates. $J$. Econ. Ent. 65, 1499-1501.

Browne, L. E., Birch M. C. and Wood D. L. (1974) Novel trapping and delivery systems for airborne insect pheromones. J. Insect Physiol. 20, 183-193.

EdGar J. A., Culvenor C. C. J. and Robinson G. S. (1973) Hairpencil dihydropyrrolizines of Danainae from the New Hebrides. J. Aust. Ent. Soc. 12, 144-150.

Fish R. H., Browne L. E., WOOD D. L. and Hendry L. B. Conversions of deuterium labelled ipsdienol with sexual and enantio-selectivity in Ips paraconfusus Lanier. Tetrahedron Lett. (In press).

Hughes P. R. (1973) Dendroctonus: production of pheromones and related compounds in response to host monoterpenes. Z. angew. Ent. 73, 294-312.

HuGHES P. R. (1974) Myrcene: a precursor of pheromones in Ips beetles. J. Insect Physiol. 20, 1271-1275.

HughiEs P. R. (1975) Pheromones of Dendroctonus: origin of alpha-pinene oxidation products present in emergent adults. J. Insect Physiol. 21, 687-691.

Hughes P. R. and Rerwick J. A. A. (1977) Neural and hormonal control of pheromone biosynthesis in the bark beetle, Ips paraconfusus. Physiol. Ent. 2, 117-123.

LeHNINGER A. L. (1970) Biochemistry. Worth, New York.

Pitman G. B., Kiseroth R. A. and Vitt J. P. (1965) Studies on the pheromone of Ips confusus (LeConte). II. Further observations on the site of production. Contr. Boyce Thompson Inst. Pl. Res. 23, 13-17.

Renwick J. A. A., Hughes P. R. and Ty T. DeJ. (1973) Oxidation products of pinene in the bark beetle, Dendroctonus frontalis. J. Insect Physiol. 19, 1735-1740.

RENWiCK J. A. A., Hughes P. R. and Krull I. S. (1976a) Selective production of $c$ is and trans-verbenol from (-) and $(+)$ alpha-pinene by a bark beetle. Science 191 , 199-201.

Renwick J. A. A., Ptrman G. B. and Virte J. P. (1966) Detection of a volatile compound in hindguts of male Ips confusus (LeConte) (Coleoptera: Scolytidae). Naturwissenschaften 53, 83-84.

Renwick J. A. A., Hughes P. R., Pitman G. B. and Vite J. P. (1976b) Oxidation products of terpenes identified from Dendroctonus and Ips bark beetles. J. Insect Physiol. 22 , 725-727.

SChNeIder D., Boppre M., Schneider H., Thompson W. R. Boriack C. J., Petty R. L. and Meinwald J. (1975) A pheromone precursor and its uptake in male Danaus butterflies. J. comp. Physiol. 93, 245-256.

Sil Verstein R. M., Rodin J. O. and Wood D. L. (1966a) Sex attractants in frass produced by male Ips confusus in ponderosa pine. Science 154, 509-510.

Silverstein R. M., Rodin J. O. and WoOd D. L. (1967) Methodology for isolation and identification of insect pheromones with reference to studies on California fivespined Ips. J. Econ. Ent. 60, 944-949.

Silverstein R. M., Rodin J. O., Wood D. L. and Browne L. E. (1966b) Identification of two new terpene alcohols from frass produced by Ips confusus in ponderosa pine. Tetrahedron 22, 1929-1936.

SMirH R. H. (1965a) Effect of monoterpene vapors on the western pine beetle. J. econ. Ent. 58, 509-510.

Smith R. H. (1965b) A physiological difference among beetles of Dendroctonus ponderosae $(=D$. monticolae) and D. ponderosae $(=D$. jeffreyi $)$. Ann. ent. Soc. Am. 58, 440-442.

Vití J. P., Bakke A. and Renwick J. A. A. (1972) Pheromones in Ips (Coleoptera: Scolytidae): occurrence and production. Can. Ent. 104, 1967-1975.

Williams V. R. and Wllliams H. B. (1967) Basic Physical Chemistry for the Life Sciences. Freeman, San Francisco.

Wood D. L. (1961) Stridulation in the genus Ips De Geer. Pan-Pacif. Ent. 37, 187-188.

Wood D. L. (1962) The attraction created by males of a bark beetle Ips confusus (Le Conte) attacking ponderosa pine. Pan-Pacf Ent. 38; 141-145.

Wood D. L. (1970) Pheromones of bark beetles. In Control of Insect Behavior by Natural Products, pp. 301-316. (Ed. by Wood D. L., Silverstein R. M. and Nakajima M.). Academic Press, New York.

Wood D. L. Bushing R. W. (1963) The olfactory response of Ips confusus (LeConte) (Coleoptera: Scolytidae) to the secondary attraction in the laboratory. Can. Ent. 95, 1066-1078.

Wood D. L. and VITE J. P. (1961) Studies on the host selection behavior of Ips confusus (LeConte) (Coleoptera: Scolytidae) attacking Pinus ponderosa. Cont. Boyce Thompson Inst. PI. Res. 21, 79-96.

Wood D. L., Browne L. E., Silverstein R. M. and Rodin J. O. (1966) Sex pheromones of bark beetles-I. mass production, bioassay, source and isolation of the sex pheromone of Ips confusus (LeC.). J. Insect Physiol. 12, 523-536.

Wood D. L., Stark R. W., Silverstein R. M. and Rodin J. O. (1967) Unique synergistic effects produced by the principal sex attractant compounds of Ips confusus (LeConte) (Coleoptera: Scolytidae). Nature 215, 206.

Wood D. L., Browne L. E., Bedard W. D., Tilden P. E. SILVERSTEIN R. M. and RoDIN J. O. (1968) Response of Ips confusus to synthetic sex pheromones in nature. Science 159, 1373-1374.

WoOd D. L., BroWne L. E., EWING B., LiNDAhL K., BEDARD W. D., Tuden P. E., Mori K., Prtman G. B. and Hughes P. R. (1976) Western pine beetle: specificity among enantiomers of male and female components of an attractive pheromone. Science 192, 896-898.

Young J. C., Brownlee R. G., Rodin J. O., Hildebrand D. B., Silverstein R. M., Wood D. L., Birch M. C. and BROWNE L. E. (1973) Identification of linalool produced by two species of bark beetles of the genus Ips. J. Insect Physiol. 9, 1615-1622. 